\title{
Nucleotide sequence of a Madagascar hepato- pancreatic parvovirus (HPV) and comparison of genetic variation among geographic isolates
}

\author{
Kathy F. J. Tang*, Carlos R. Pantoja, Donald V. Lightner \\ Department of Veterinary Science and Microbiology, University of Arizona, Tucson, Arizona 85721, USA
}

\begin{abstract}
A segment of Madagascar hepatopancreatic parvovirus (HPV) genomic sequence (5742 nucleotides) was determined through PCR and direct sequencing. This nucleotide sequence was compared to isolates from Australia, Thailand, Korea, and Tanzania, and the mean distance was determined to be $17 \%$. The Madagascar HPV is closest to the Tanzania isolate $(12 \%)$, followed by isolates from Korea (15\%), Australia (17\%) and Thailand $(20 \%)$. Analysis of the genomic structure revealed that this HPV sequence is comprised of one partial Left open reading frame (ORF) (349 amino acids, aa) and complete Mid (578 aa) and Right (820 aa) ORFs. The amino acid sequences of the 3 ORFs were compared among isolates. The Right ORF was found to have the highest variation with a mean distance of $24 \%$. This was followed by the Left and Mid ORF with distances of 13 and $7 \%$, respectively. A phylogenetic analysis based on the amino acid sequence of the Right ORF divides 7 HPV isolates into 3 well-separated groups: Korea, Thailand, and Australia. The Madagascar HPV clustered with the Korea and Tanzania isolates. In Madagascar, HPV has been detected by histological examination since the 1990s. PCR analysis of a recent (2007) sampling showed a $100 \%$ prevalence. HPV was also detected in Mozambique with a $100 \%$ prevalence. High (95\%) prevalence of HPV was found in wild Penaeus merguinesis collected from New Caledonia. These results indicate that HPV displays a high degree of genetic diversity and is distributed worldwide among populations of penaeid shrimp.
\end{abstract}

KEY WORDS: Hepatopancreatic parvovirus $\cdot \mathrm{HPV} \cdot$ Genetic variation $\cdot$ Madagascar isolate

\section{INTRODUCTION}

Hepatopancreatic parvovirus (HPV) is a shrimp virus that has been linked to growth retardation through statistical correlations (Flegel et al. 1999), and this indicates that the virus can present a risk to commercial shrimp farming. The virus was discovered in cultured Penaeus merguiensis in Singapore in 1982 (Chong \& Loh 1985) and was associated with poor growth and high mortalities (up to $100 \%$ ) in larval and postlarval $P$. chinensis, juvenile $P$. merguiensis and $P$. semisulcatus (Lightner \& Redman 1985, Lightner 1996). This virus has since been detected in a number of other penaeid species, both from cultured and wild stocks, around the world. It has been detected in shrimp from Indo-
Pacific Africa, Australia, Asia, and the Middle East (Roubal et al. 1989, Flegel et al. 1992, Spann et al. 1997).

HPV is a small (22 to $24 \mathrm{~nm}$ ), icosahedral, nonenveloped virus containing a single-stranded linear DNA genome of ca. $6 \mathrm{~kb}$ with a hairpin structure at both $5^{\prime}$ and $3^{\prime}$ ends (Bonami et al. 1995, Sukhumsirichart et al. 2006, La Fauce et al. 2007). Based on morphological and biochemical characteristics, HPV is taxonomically placed within the family Parvoviridae (Bonami et al. 1995). It contains 3 large open reading frames (Left, Mid and Right ORF). The Left ORF may encode a non-structural protein 2 (NS2) of 428 amino acids (aa). The Mid ORF could encode a non-structural protein 1 (NS1) with a length of 579 aa (or 578 aa by La 


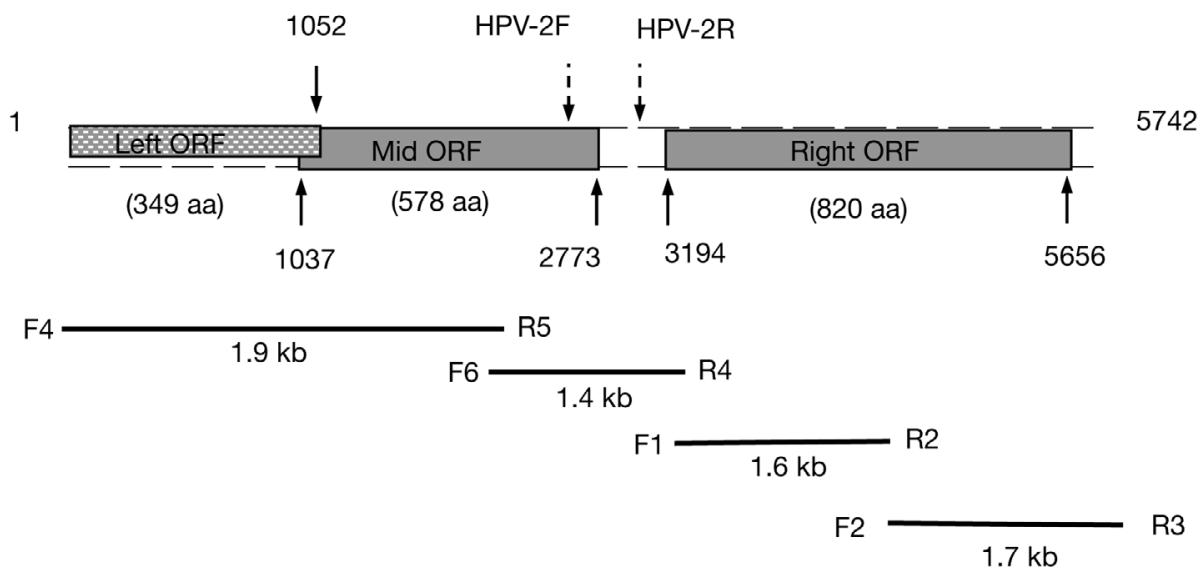

Fig. 1. Genomic organization of Madagascar hepatopancreatic parvovirus (HPV). A 5742 nt viral sequences was assembled from 4 amplicons. ORF: open reading frame; aa: amino acids

Fauce et al. 2007). The Right ORF starts 424 nucleotides (nt) downstream from the Mid ORF and may encode a 820 aa polypeptide that consists of a viral capsid protein (Sukhumsirichart et al. 2006). One major (57 kDa) and 2 minor (92 and $54 \mathrm{kDa}$ ) structural proteins were detected in the viral preparation, indicating a post-translational modification for genesis of the viral capsid protein.

HPV has been suggested to be more similar to the autonomous parvoviruses than to the insect densoviruses based on the genomic structure and the number of capsid proteins (Bonami et al. 1995). Recently, a marked divergence, $17 \%$ difference in nucleotide sequence, was also found when comparing Australia HPV to the Thailand isolate (La Fauce et al. 2007). In the present study, we sequenced $91 \%$ of the genomic sequence of a Madagascar HPV isolate and compared it with 4 other isolates (Thailand, Australia, Korea, and Tanzania) and showed a $17 \%$ (mean) difference. This indicates a high genetic diversity among HPV isolates. In addition, HPV also had a high prevalence (near

Table 1. Primers used in determining Madagascar hepatopancreatic parvovirus (HPV) sequence

\begin{tabular}{|c|c|}
\hline $\begin{array}{l}\text { Primer } \\
\text { designation }\end{array}$ & Sequence of primer \\
\hline HPV-F4 & 5'-GATAAGTGCGGTGCGGC-3' \\
\hline HPV-R5 & 5'-TTCAATGTAATCTGCCTGCTG-3' \\
\hline HPV-F6 & 5'-TTGGAGAAGTATTTGGTAAAGCA-3' \\
\hline HPV-R4 & 5'-TCСTCСТTTTCTTGTAGGTGACA-3' \\
\hline HPV-F1 & 5'-TGAGACAGGGCCATATGCTA-3' \\
\hline HPV-R2 & 5'-TTGTCATGTCGAATCCTTGG-3' \\
\hline HPV-F2 & 5'-CACGCAAGAGCGACAAGATA-3' \\
\hline HPV-R3 & 5'-TCGCTTCTTTTGAAGGGTAAC-3' \\
\hline
\end{tabular}

$100 \%$ ) in cultured and wild penaeid shrimp collected from West Indian Ocean and New Caledonia.

\section{MATERIALS AND METHODS}

Virus isolate. Samples of HPV-infected Penaeus monodon were collected from 2 separate farms in Madagascar, Farm 1 (2006) and Farm 2 (2007), and kept frozen at $-70^{\circ} \mathrm{C}$ in the Aquaculture Pathology Lab at the University of Arizona. The HPV sequenced in the present study was from a single individual shrimp collected in Farm 2, which had a much more severe infection (see the result of PCR detection in Fig. 4B). The HPV-infected Penaeus monodon samples from Pemba, Mozambique, preserved in $95 \%$ ethanol, were sent from a farm in 2005. The $P$. monodon samples from Indonesia were sent from a farm in 2003. The $P$. monodon (postlarvae) samples from Tanzania were sent from a farm near Dar es Salaam in 2008. Thirty individual HPV-infected hepatopancreas tissue samples of $P$. merguiensis (wild shrimp) were sent from New Caledonia in 2006.

Determination of Madagascar HPV sequence by PCR and DNA sequencing. DNA was extracted from a hepantopancreas sample of penaeid shrimp with a High-Pure DNA template preparation kit (Roche Bioscience) and amplified with HPV-specific primers (Table 1). The amplicons were purified with a QIAquick PCR purification kit (Qiagen) and sequenced using an automatic DNA sequencer (3730 DNA analyzer, Applied Biosystems), at the University of Arizona. Sequencing of 4 PCR amplicons (1.4 to $1.9 \mathrm{~kb}$, Fig. 1) has allowed determination of a $5742 \mathrm{nt}$ genomic sequence of Madagascar HPV (GenBank no. EU247528). 
Analysis of HPV genomic sequence. The nucleotide sequence of HPV was compared among 5 isolates: Korea (GenBank no. AY008257), Thailand (DQ002873), Australia (DQ458781), Tanzania (EU588991), and Madagascar (EU247528). Molecular evolutionary genetics analysis (MEGA) (Tamura et al. 2007) was used to estimate nucleotide distances between pairs of sequences using the Kimura 2parameter method. The amino acid sequences of the Right ORFs were used to construct a phylogenetic tree. Seven isolates were included in the analysis: 5 as described above plus Indonesia (EU290601) and New Caledonia (EU346369). Following multiple sequence alignment, a neighbor-joining phylogenetic tree was constructed (Saitou \& Nei 1987). The data were resampled by 1000 bootstrap replicates to determine the confidence indices within the tree.

HPV diagnostic PCR. DNA was extracted from hepantopancreas of individual shrimp and amplified by PCR through the use of PuReTaq Ready-To-Go PCR beads (GE Healthcare). The HPV primers are HPV-2F (5'-GGAAGCCTGTGTTCCTGACT-3') and HPV-2R (5'-CGTCTCCGGATTGCTCTGAT-3'). The location of the primers is shown in Fig. 1. The sequence of primers was selected based on the Indonesia isolate (EU290601), and the primers were used to amplify a $595 \mathrm{nt}$ viral fragment. This pair of primers has 1, 5, 4, 5 and 6 mismatched nucleotides to the target sequence in isolates of Madagascar, Tanzania, Korea, Australia, and Thailand, respectively, but proved to be capable of amplifying all 5 isolates. The amplification was carried out as follows: initial denaturation at $94^{\circ} \mathrm{C}$ for $5 \mathrm{~min}$, followed by 35 cycles of $94^{\circ} \mathrm{C}$ for $30 \mathrm{~s}, 55^{\circ} \mathrm{C}$ for $30 \mathrm{~s}, 72^{\circ} \mathrm{C}$ for $30 \mathrm{~s}$ and a final extension at $72^{\circ} \mathrm{C}$ for 7 min. After PCR, an aliquot of the PCR reaction mixture was visualized in a $1.5 \%$ gel and then photographed.

\section{RESULTS}

The HPV from infected Penaeus monodon cultured in Madagascar was partially sequenced (5742 nt) by assembling 4 PCR DNA fragments amplified from the viral DNA (Fig. 1). The sequence contains ca. $91 \%$ of the entire viral genome (6321, Sukhumsirichart et al. 2006). This Madagascar HPV included a full length of Mid (578 aa) and Right (820 aa) ORFs and a partial Left ORF (349; aa, 428 aa is the full length) (Fig. 1). The Left and Mid ORFs have different reading frames; the $3^{\prime}$ end of Left ORF overlaps (16 nt) with the Mid ORF. The
Table 2. Pairwise distance (\%) among 5 hepatopancreatic parvovirus (HPV) isolates. (A) Genomic DNA sequence, (B) amino acid (aa) sequence of Left ORF (open reading frame), (C) Mid ORF and (D) Right ORF

\begin{tabular}{|c|c|c|c|c|}
\hline $\begin{array}{l}\text { (A) Genomic } \\
\text { DNA }\end{array}$ & $\begin{array}{l}\text { Madagascar } \\
\quad(5742 \mathrm{nt})\end{array}$ & $\begin{array}{l}\text { Korea } \\
\text { (5740 nt) }\end{array}$ & $\begin{array}{l}\text { Thailand } \\
\text { (6321 nt) }\end{array}$ & $\begin{array}{l}\text { Australia } \\
\text { (5936 nt) }\end{array}$ \\
\hline Korea & 15 & - & - & - \\
\hline Thailand & 20 & 20 & - & - \\
\hline Australia & 17 & 16 & 21 & - \\
\hline Tanzania (5685 bp) & 12 & 15 & 20 & 18 \\
\hline (B) Left ORF & $\begin{array}{l}\text { Madagascar } \\
\text { (349 aa) }\end{array}$ & $\begin{array}{l}\text { Korea } \\
\text { (348 aa) }\end{array}$ & $\begin{array}{l}\text { Thailand } \\
\text { (428 aa) }\end{array}$ & $\begin{array}{c}\text { Australia } \\
\text { (372 aa) }\end{array}$ \\
\hline Korea & 13 & - & - & - \\
\hline Thailand & 13 & 10 & - & - \\
\hline Australia & 17 & 15 & 13 & - \\
\hline Tanzania (344 aa) & 1 & 13 & 13 & 17 \\
\hline (C) Mid ORF & $\begin{array}{l}\text { Madagascar } \\
\text { (578 aа) }\end{array}$ & $\begin{array}{l}\text { Korea } \\
\text { (578 aa) }\end{array}$ & $\begin{array}{l}\text { Thailand } \\
\text { (579 aa) }\end{array}$ & $\begin{array}{c}\text { Australia } \\
\text { (578 aa) }\end{array}$ \\
\hline Korea & 5 & - & - & - \\
\hline Thailand & 8 & 7 & - & - \\
\hline Australia & 7 & 7 & 7 & - \\
\hline Tanzania (578 aa) & 2 & 5 & 9 & 8 \\
\hline (D) Right ORF & $\begin{array}{c}\text { Madagascar } \\
\text { (820 aa) }\end{array}$ & $\begin{array}{c}\text { Korea } \\
\text { (820 aa) }\end{array}$ & $\begin{array}{l}\text { Thailand } \\
\text { (818 aa) }\end{array}$ & $\begin{array}{c}\text { Australia } \\
\text { (819 aa) }\end{array}$ \\
\hline Korea & 18 & - & - & - \\
\hline Thailand & 30 & 28 & - & - \\
\hline Australia & 24 & 24 & 31 & - \\
\hline Tanzania (821 aa) & 18 & 14 & 28 & 25 \\
\hline
\end{tabular}

Mid and Right ORFs are in the same reading frame with a $424 \mathrm{nt}$ gap in between. The nucleotide sequence was compared with that of 4 other HPV isolates: Korea, Thailand, Australia, and Tanzania. The results showed an overall mean variation of $17 \%$, with largest distance (21\%) between Thailand and Australia isolates (Table 2A). The pairwise distance comparisons showed that Madagascar HPV is closest to the Tanzania isolate $(12 \%)$, followed by Korea (15\%), Australia (17\%), and Thailand $(20 \%)$.

The amino acid sequence of each ORF was also compared among 5 isolates. For the Left ORF, the overall mean variation is $13 \%$; the Madagascar isolate showed a distance of only $1 \%$ to Tanzania, $13 \%$ to both Korea and Thailand and increased to $17 \%$ to the Australia isolate (Table 2B). For the Mid ORF, the overall mean variation is the lowest, $7 \%$. Again, the Madagascar HPV is closest to that of Tanzania, $2 \%$, and increased up to $8 \%$ to the Thailand isolate (Table $2 \mathrm{C}$ ). For the Right ORF, the overall distance is the highest, $24 \%$. The largest distance, 31\%, is between the Thailand and Australia isolates (Table 2D). Madagascar HPV is 


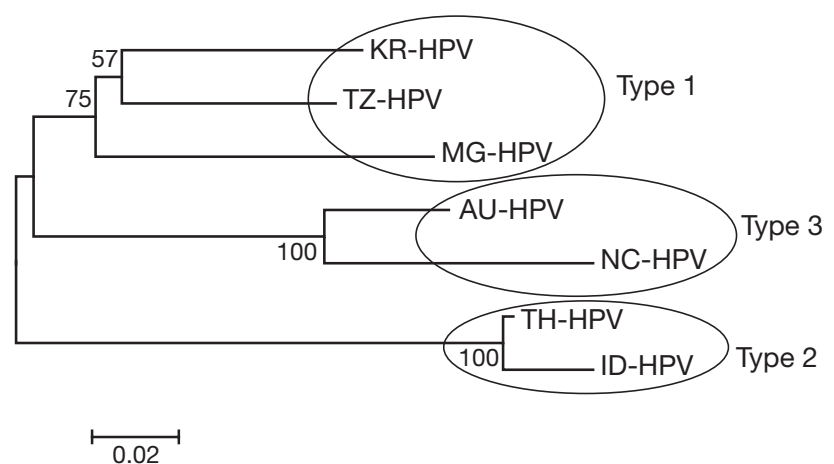

Fig. 2. Phylogenetic relationship among 7 hepatopancreatic parvovirus (HPV) isolates based on the Right ORF (open reading frame) amino acid sequence. The tree was constructed using the neighbor-joining with the molecular evolutionary genetics analysis (MEGA) program. Numbers indicate the percentages of boostrap support from 1000 replicates. Isolates were collected from Korea (KR), Tanzania (TZ), Madagascar (MG), Australia (AU), New Caledonia (NC), Thailand (TH), and Indonesia (ID)

closest $(18 \%)$ to both the Tanzania and Korea isolates and less similar to the Thailand isolate (30\%).

Phylogenetic analysis revealed 3 genotypes of HPV: Korea (Type 1), Thailand (Type 2), and Australia (Type 3) from 7 HPV isolates (Fig. 2). The Madagascar, Tanzania, and Korea isolates were grouped together with a boostrap value of $75 \%$. The New Caledonia and Australia isolates clustered into one group with a bootstrap value of $100 \%$. The New Caledonia isolate showed $90 \%$ identical to the Australia isolate in the translated Right ORF aa sequence and has only 71 to $76 \%$ identities to Thailand, Korea, Tanzania, and Madagascar isolates. HPV from Indonesia and Thailand are closely related and clustered together with a boostrap value of $100 \%$. The Indonesia isolate has available sequence for the 392 aa at the N-terminus of Right ORF and showed $97 \%$ identity with the Thailand isolate. This phylogenetic tree did not group the 4 isolates (Madagascar, Tanzania, Thailand, and Indonesia) from the same host (Penaeus monodon) into one group, and there were no unique aa substitutions that are specific to HPV from infected $P$. monodon.

There were 328 aa changes within the 821 aa region of the $7 \mathrm{HPV}$ isolates (Fig. 3), and 250 aa changes (76\% of the variable aa) are in the major capsid protein (57 $\mathrm{kDa}$ ) coding region. The N-terminus of the $57 \mathrm{kDa}$ capsid protein starts at aa 272 (Fig. 3, alanine residue for the Thailand isolate, Sukhumsirichart et al. 2006). Comparing the complete Right ORF from 6 isolates (excluding Indonesia), the mean distance for the region encoding the $57 \mathrm{kDa}$ capsid protein (after aa 272 ) is $29 \%$, higher than the region of 1 to 271 aa, which has a mean distance of $14 \%$.
Within the first one-third of the Right ORF, there is a conserved domain (COG4942) of membrane-bound metallopeptidase present within aa no. 61 to 219. This domain is usually found in the genes of bacteria which are responsible for cell division and chromosome partitioning. However, this conserved domain was also found in an iridovirus that infects fish (Zhang et al. 2004).

HPV has been found in Madagascar since the early 1990s by histology. The infection by HPV was monitored by PCR in a farm (Farm 1) in Madagascar in 2006. We found 6 out of 13 Penaeus monodon were weakly positive (Fig. 4a). Strong positive HPV was detected in all 11 samples from Farm 2 in 2007 (Fig. 4b). HPV was also found in a farm located in Mozambique in 2005 by histological examination (10 out of 27 postlarval and 1 out of 5 juvenile samples examined). However, by PCR, 14 out of 14 samples were strongly positive (Fig. 4c). The Mozambique HPV isolate was shown to be very similar (98\% identical in nucleic acid sequence of a $2.5 \mathrm{~kb}$ fragment of Right ORF) to the Madagascar isolate. HPV was also detected in wild populations of $P$. merguiensis collected in 2006 in New Caledonia, with 19 out of 20 individual shrimp positive for HPV (Fig. 4d).

\section{DISCUSSION}

A $5.6 \mathrm{~kb}$ genomic sequence was compared among HPV isolates and a high level of genetic variation (mean distance: 17\%) was revealed (see Table 2A). The highest nucleotide variation was found in the region of Right ORF, which encodes the major capsid protein. Although a limited number of HPV isolates are used in the present study, based on the phylogenetic tree constructed from the amino acid sequence of the Right ORF, we tentatively divided the isolates into 3 genotypes: 1 (Korea), 2 (Thailand), and 3 (Australia). The variation appears to be primarily associated with the geographic distribution of the host. For example, HPV samples collected from Queensland, Australia, and New Caledonia, which are both in the South Pacific and separated by only ca. 600 miles (ca. $1000 \mathrm{~km}$ ), clustered together. Similarly, isolates from Thailand and Indonesia, both in the South Pacific and separated by a few hundred miles (ca. $350 \mathrm{~km}$ ), clustered together. An exception was the cluster that contained the isolates from Madagascar, Tanzania, and Korea. However, the bootstrap value was low, only $75 \%$, for this grouping and should be considered tentative until more isolates are analyzed.

HPV appears to have greater genetic diversity than other shrimp viruses. For example, infectious hypodermal and hematopoietic necrosis virus (IHHNV), 
MG-HPV : MSPTRKGGNYFASKHFQNKRKNKLGKVKDLLASKKKERKFKGKGNTLSEEPSTSGWQDPVRRRFPALEOE TZ-HPV : MSPTRKGGNYFASKHFQNKRKNKLGKVKDLLASKKKERRFKGKGNTLDEQPSTSGWKDPVRQRFPALEQE KR-HPV : MSPTRKGGNYFASKHFQSKRKNKLGKVKDLLASKKRERKFKGKGNTLSEEPSTSGWKDPVRQRFPALEQE AU-HPV : MSPTRRGGNYFASKHFQGKRKSKLQRVKDLLASKKKDRKFKGKGNTLSEEPSTSGWRDPVRQRFPALGQE NC-HPV : MPPTRKGGNYFASKHFQTKRKSKIQRVKEFLESKRKDRRFKGKGNTLSEEPSTSGWRDPVRQRFPALKDG TH-HPV : MSPTRKGGNYYASKHFQSKRKNKLARVKDLLASKKKERRFKGKGNTLSEKPSTSEWNDPVRQRFPELEQE ID-HPV : MSPTRKGGNYYASKHFQSKRKNKLARVKDLLASKKKERRFKGKGNTLSEKPSTSEWNDPVRQRFPELEQE

\section{0}

100

120

140

MG-HPV : ERNTFAGLLAIEAAPDOROLGRDNNNOLALVORDTRVAVROSTNRREALEVVKAANOAIRSGGDRLAEIV TZ-HPV : KR-HPV : AU-HPV : NC-HPV : TH-HPV : ID-HPV :

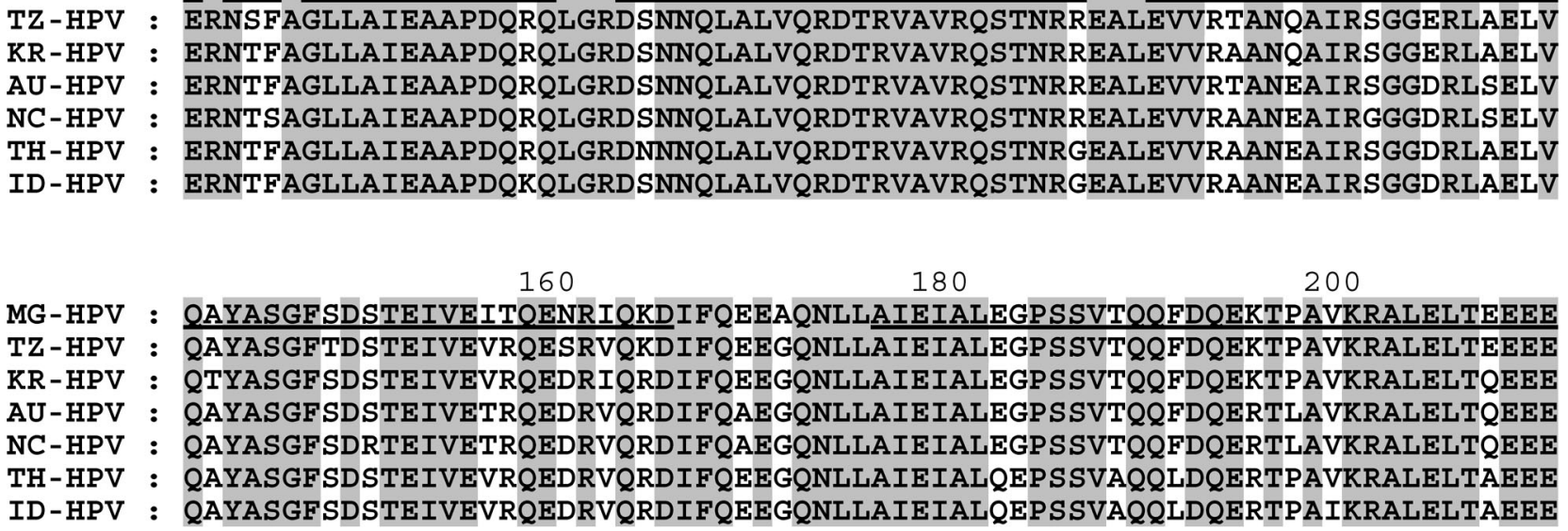

\section{0}

240

260

$\downarrow \quad 280$

MG-HPV : QIERIENAKKYIEEVIEETNQELANQERQETSASEEDTMSSAAPTPMETSESGVTAAPHQRSAAGSGGGG TZ-HPV : QIERIENAKKYIEEVIEETNQELANQERQETSASAEDTMSTAAPTPMETSEPGVTAAPHQRAASGGSGGG KR-HPV : QLERIENAKKYIEEVIEETNREFESEVRQETSAEAEDTMASAAPTPMETSEPGVTAAPHQKSAAGGGGGG AU-HPV : RIEQIENAKKYIEEVIDETNRELATQERQDISAAAEDTMNSAAPTPMETSEPGTTAAPQQLSAAGGGGGG NC-HPV : RIERVENAKKYIEEVIEETNRELATEERQDISAAADDTMNSAAPTPMETSEPGTTAAPQQLSASGGGGGG TH-HPV : RIERIENAKKYIEEVIEETNQELQEQERQEVSAAAEDTMNTEAPVPMETSESGATAAPQQRAAAGGGGSG ID-HPV : RIERIENAKKYIEEVIEETNQELQEQERQEVSAAAEDTMNTEAPVPMETSESGATAAPQQRAAAGGGGSG

\section{0}

320

340

MG-HPV : GGSGGETAGYGKNTNDAFQRHRNKPIDLKHIGDNVYVAQRVYKVESECKLVHDKLTWSATSDNAYTRRLM TZ-HPV : GGSGGETAGYGKNTNDAFQRHRNKPIDLKHIGDNVYVAQRVYKVEAECKLVNDKLVWSETEDSGYVRRLM KR-HPV : GGSGGETAGYGKNTNDAFQRHRNQP IDLKHIGDNVYVAQRVYKVEAECKLIHDKLTWSATADNP FVRRLM AU-HPV : GG-GGETAGYGKNTGSAFQRHRNKPIDLQHIGDNVYVAQRVYKVEAECKLVNNKLTWQATEDNPFTRRLM NC-HPV : GG-GGETAGYGRNTSSAFQRHRNKPIDLKHIGDNVYVAQRVYKVEAECVLVYNKLTWNTTEDNPFTRRLM TH-HPV : GG--GESAGYGKNPSDSFQRHRNKPVDLKHIGDNVYVAQRVYKVEAECKLVGDKLSWSNTTNSKYLRRLL ID-HPV : GG--GESAGYGKNPSDSFQRHRNKPVDLKHIGDNIYVAQRVYKVEAECKLVGDKLSWNNTTNSKYLRRLL

$$
360
$$

380

400

420

MG-HPV : GLEKDHDQGAIKFSYKSILNGSITMGNLALGNYINAWGIDNIAKSEDSWAIIATRGKMNHLQAFEMIPQM TZ-HPV : GLNESSNQGDIKYSFNALLHGS IGLGNLALSNYINAWGLDNIAKSEDSWAIIATRGKMNHLQAFEMIPQM KR-HPV : GLNESSNSGDIKYSFNALLHGSIGLGNLALSNYINAWGIDNMAKSEDSWAIIATRGKMNHLQAFEMIPQM AU-HPV : GLSSASNQGNFKYSFKSILGGSVCLGNLNLSNYINAWGIDNIAKSEDSWAILCTRGKMNHLQAFEMIPQL NC-HPV : GLSSASNQGDFKYSFKSILGGS INMGNLNLCNYINAWGIDNIAKSEDSWAILCTRGKMNHLQAFEMIPQL TH-HPV : GINGNSNSGDIKHSFYTQLSGSIGLGNLALGNYINSWGMDNISKSEDSWAIIATRGKMNHLQAFEMVPQY ID-HPV : GINGNSNKGDIKHSFYTQLSGSIGLGNLALGNYINSWGMDRDSR -

Fig. 3. Above and following page. Amino acid sequence alignment of translated Right ORF (open reading frame) of hepatopancreatic parvovirus (HPV). Seven isolates are the same as described in Fig. 2. Dashes (- - -): amino acid sequence not available. A conserved domain for membrane-bound metallopeptidase (COG4942) is underlined. ( $\downarrow$ ): first N-terminus amino acid of the major capsid protein. Identical amino acids are shaded 
MG-HPV : QGETVVGYTSAPVQFGKLLGHVYYPDPKGEEKIKVANSDNGREVKVFDGALEGYKLDDDMNQKKITADQH TZ-HPV : QGETITGYTSAPVQFGKLLGHVYYPDPKGEEKIKVANNSNGKEYKIFDGATDGLTLDDDMNQKKITADQH KR-HPV : QGETIVGYTSAPVQFGKLLGHIYYPDPKGEEKIKVANHSNGQEYRIFDGALDGYTLDDDMNQKKITADQH AU-HPV : QGETVIGYTSAPVQFGKLLGHIYYPDPKGEETIKVAGIGNGKESQVFEGAQEGYLMDDDMSQKKITSEAH NC-HPV : QGETVVGYTSAPVQFCKLLGHIYYPDPKGEETIKVAGIANGKESQAFNGAKEGYLMDDDMSQTKITSEEH TH-HPV : QGETVVGYTSAPLQFGKLLGHVYYPDPKGEERIKIASKADAKESKMFKDAMAGYLLDDDMNQTKVTSEHN ID-HPV :

MG-HPV : HVYMFTDLRDAPMISEVAAYLNTANPQQINGIGMEHQGYDVAGGENTSFIGVTPSNCIERRKEIQSGMDN TZ-HPV : HVYMFTDLRDAPMMSAVTAYLNTDTPAQINGIGIEHQGFDMTSDPNTALIGVMPSNCIQKRKEIQSGMDN KR-HPV : HVFMFTDLRDAPMISEVTAYLNTDNPAQINGIGIEHQGFDMSNDANTALIGVMPSNCIRKRKEIQSGMDN AU-HPV : PVYMFTDLRDAPMISEVTAYLDSTNPTRISSVGVEHQGFDMTNDANTALIGVTPSNCIQRRKEIQSGMDD NC-HPV : SVCMFTDLRDAPMISEVTAYLAVPDQDRIHSIGIEHQGFDMTNDANTALIGVTPSNCMQRRKEIQSGMDD TH-HPV : HVFAFTDLRDSPVISEVAAYQTNDEPPKINGIGIEYQGFNLTSDTNAALIGLMPSNCIKRRKEIQSGMDN ID-HPV

MG-HPV : VVLWSMKSNRLIDKRFWTPEGWSNKSANGMANDRVELPSEGAPIFDEAHVTRTSDYAEWARNEIFYDGTA TZ-HPV : VVLWSMKSNRLIDKRFWTPEGWSHKSMNGMANDRVDIPIEGDAIFDEAHVTRTSPYAEWARNEIFYSADV KR-HPV : VVLWSMQSNRLIDKRFWTPEGWSLKSVNGMANDRIDMPSEGAAIFDEAHVTRTSNYAEWARNEIYYSADT AU-HPV : VVIWSMKSNKLIDKRFWKPEGWSSKSLNGMANNRIDIPAEGAPIYEDAYVCRTSDYAGWARTEVFYDANT NC-HPV : VVIWSMKSNKLIDKRFWRPEGWSNKSLNGMANNRVDIPAEGAPIYEDAYVCRTSGYAEWARTEVFYDANT TH-HPV : VVLWSMKSNRLIDKRFWKPEGWTKKSMNGMAKDKVNITPTTYDIYEEAHVTRTTDYAEWARNEIFYDANT ID-HPV :

640

MG-HPV : SYSEFAPGNNGAFVQKYNIGNQYATNVFFMPYAHTQRGAIQDIVINFDLTLQIMVKRIPRHVYNDFYHVN TZ-HPV : SDNAYAPGNPGAFTQKYNIGNQYATSIFFMPYAHTQRGAIQDIVINFDLTLQIMVKRIPRHVYNDFHHVN KR-HPV : SDNAFGPSNTGAFAQKYNVSNQYATNIFFMPYAHTQRGAIQDIVINFDLTLQIMVKRIPRSVYNDFYHIN AU-HPV : EYSEFAPGNTGAFTQKYNMSNQYATCIFFMPYAHTQRGAIQDIVINFDLTLQIMVKRIARHVYNDFYHVN NC-HPV : EYSEFAPGNTGAFTQKYNMSNQYATCIFFMPYAHTQRGAIQDIVINFDLTLQVMVKRIARHVYNDFYHIN TH-HPV : SYGSVGPSDIGNFVQKYNLSDQYATDIF FMPYVHTQRGIIQDIVINFDLTMQIMVKRIPRQVYNDFYHIN ID-HPV

\section{0}

740

760

MG-HPV : AKAVVPVVYDNYIDRPYTGAQISHRAQNLHINMSGTHGSKYADRGQISRKGATMKDFGKRPYGQRTILLN TZ-HPV : AKAVTPIVYDEYKARTYGAQQIKNRAQNLHINMTGTHGSKYSDRGQASNKRAVKKNSATRAYAQRLLLLN KR-HPV : ARAVVPTVYDEYKDRTFGATEISHRGKNIHVNITGTHGSKYSDRGQVSRIGATKKNFATRAYGQKQLLLN AU-HPV : TKAAHPVVYEKFEERSFGADNIKHRAHNIHVNMSGTHGSKYSDRGQVSRKKAIKADHDKRPYGQRRIMVE NC-HPV : TGGVHPVVYTKFEERSFGDDNIKHRAHNIHVNMSGTHGSKYADRGQVSRKKAIKADRDKRPCGQRRLMIE TH-HPV : TRAMNPVKYDSAVERSFGYDEIYARSIKIHENISGTHGSKYADRGPISHMEATKRNSYQRAYAQRRIILD ID-HPV : - - -

\section{0}

800

820

MG-HPV : EGIPTRRTRSS-AAAEDDIPEDCDDFLETSEMEPPPQPQLQKKKKKPKTNV TZ-HPV : EGITRRTTRSSAAAAEDDIPEDCGDFLETSEMRPPPQPQLPKKKKKYRTDV KR-HPV : EGITRRKTRSS-AAAEDDIPEDCEDFLETSEMESPPQPQLQKKKKKYKTNV AU-HPV : EESPVRRTRSS-AAAEDDIPEDCDDFLETSEMESPPQPQLPKKKKKYRTVM NC-HPV : VGAGPMRTRSS-AAAEDDIPEDCDDFLETSEMESPPQPQLPKKKKKYRTNV TH-HPV : QGVSKMKTRSS-AAAEDDIPEDCDDFLETSEMDPPPQPQLPKKKKKYRVNV ID-HPV : 


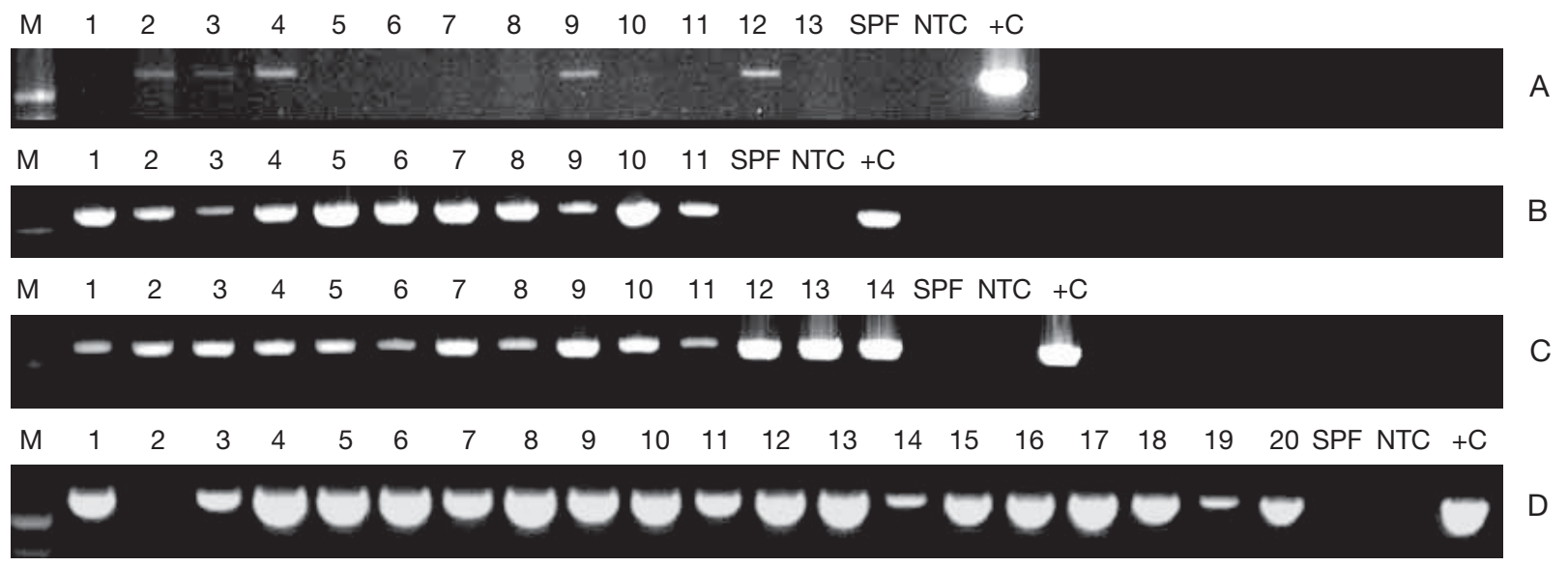

Fig. 4. PCR detection of hepatopancreatic parvovirus (HPV) in Africa Penaeus monodon and New Caledonia P. merguinesis. PCR primers HPV-2F/2R were used to amplify a $595 \mathrm{nt}$ viral DNA fragment. M: $1 \mathrm{~kb}$ DNA ladder; SPF: DNA extracted from specificpathogen-free shrimp; NTC: non-template control; +C: positive control. (A) Madagascar Farm 1, (B) Madagascar Farm 2, (C) Mozambique farm, and (D) New Caledonia wild stocks

another parvovirus, displays only $4 \%$ variation in nucleotide sequences (Tang et al. 2003), and Taura syndrome virus (TSV), a dicistrovirus, shows less than $6 \%$ difference in nucleotide sequence among isolates (Tang \& Lightner 2005). The higher variation in HPV may reflect the fact that it is found over a much wider geographic area than the others. HPV has been found in samples of penaeid shrimp collected from Africa, Australia, and Asia. IHHNV, on the other hand, is known to originate from Asia and was introduced to stocks in the Western Hemisphere (Lightner 1999, Tang et al. 2003). Similarly, TSV was discovered in Ecuador (Hasson et al. 1995, Lightner et al. 1995) and had since spread to the Americas and to Southeast Asia.

Severity of HPV infection varies with life stage and most readily infects larvae, postlarvae and very early juveniles (Lightner 1996). Our laboratory infection of juvenile (0.5 to $1 \mathrm{~g}$ ) Penaeus monodon with Madagascar HPV through per os exposure was not successful (data not shown). In contrast, postlarvae of $P$. monodon became infected through per os exposure, and the percentage of shrimp infected did not increase as the shrimp developed into the juvenile stage.

Although HPV may be highly infectious in wild populations, its effects on shrimp growth are not clear. A high prevalence of HPV was found in wild populations of Penaeus merguinesis in New Caledonia (95\%, Fig. 4D) and P. monodon in Madagascar (over $90 \%$ by histology, M. Le Groumellec pers. comm). This suggests that, in the wild, HPV is very transmissible, but reports of the impact of this virus on farmed shrimp are conflicting. HPV has been linked to growth reduction of farmed P. monodon in Thailand (Flegel et al. 1999); in Madagascar, HPV infection appears to have no negative effect on shrimp growth (M. Le Groumellec, AQUALMA, Madagascar, pers. comm.). The different effects reported from different areas may be related to differences among viral genotypes, host populations and/or farming practices. For example the Thailand isolate differs from the Madagascar isolate by $20 \%$ in nucleotide sequence and was shown to be a different genotype. Another possibility is that this results from the difference in the host populations. It has been shown that the population of $P$. monodon in the Indian Ocean is genetically different from the Western Pacific Ocean population (Duda \& Palumbi 1999). Also, the high stocking density is shown to result in reduced growth due to competition for space and food (Maguire \& Leedow 1983). Farmed shrimp are stocked at a density of 10 to $15 \mathrm{~m}^{-2}$ in Madagascar and, generally, over $75 \mathrm{~m}^{-2}$ in Thailand. The stunted growth reported in HPV-infected P. monodon cultured in Thailand may be related to the high stocking density.

In hatcheries, HPV transmission usually occurs during spawning, the eggs being contaminated by feces from the broodstock. This can be reduced by egg/nauplii disinfection procedures (FAO 2007), such as practiced in Farm 1 in Madagascar, where only ca. half the farmed population was infected and then only weakly positive (Fig. 4A). The effects of Madagascar HPV on shrimp growth need to be clarified through controlled experiments. This is important because African stocks of Penaeus monodon are often used as broodstock in other areas of the world. This is because African $P$. monodon stocks are known to be free of the major infectious shrimp viruses: white spot syndrome virus (WSSV), TSV, IHHNV, yellow head virus (YHV), and 
infectious myonecrosis virus (IMNV). However, in Madagascar and Mozambique, nearly $100 \%$ of both wild and farmed populations are infected with HPV. If Madagascar HPV has a negative impact on shrimp growth, then stocks need to be monitored for HPV prior to shrimp being stocked in growout ponds or exported as broodstock.

Acknowledgements. This work was supported by USDA Hatch Funds, Darden Restaurants and Morrison Enterprises. We thank Dr. M. Le Groumellec for providing Penaeus monodon from Madagascar and Dr. I. Mermoud for providing $P$. merguiensis from New Caledonia.

\section{LITERATURE CITED}

Bonami JR, Mari J, Poulos BP, Lightner DV (1995) Characterization of hepatopancreatic parvo-like virus, a second unusual parvovirus pathogenic for penaeid shrimps. J Gen Virol 76:813-817

Chong YC, Loh H (1985) Hepatopancreas clamydial and parvoviral infections of farmed marine prawns in Singapore. Singapore Vet J 9:51-56

Duda Jr TF, Palumbi SR (1999) Population structure of black tiger prawn, Penaeus monodon, among western Indian Ocean and western Pacific populations. Mar Biol 134: 705-710

FAO (Food and Agriculture Organization) (2007) Improving Penaeus monodon hatchery practices. Manual based on experience in India. FAO Fisheries Technical Paper No. 446. FAO, Rome

Flegel TW, Fegan DF, Kongsom S, Vuthikorn-udomkit S and others (1992) Occurrence, diagnosis and treatment of shrimp diseases in Thailand. Diseases of penaeid shrimp. In: Fulks W, Main KL (eds) Diseases of cultured penaeid shrimp in Asia and the United States. Oceanic Institute, Honolulu, HI, p 57-112

Flegel TW, Thamavit V, Pasharawipas T, Alday-Sanz V (1999) Statistical correlation between severity of hepatopancreatic parvovirus infection and stunting of farmed black tiger shrimp (Penaeus monodon). Aquaculture 174: 197-206

Hasson KW, Lightner DV, Poulos BT, Redman RM, White BL, Brock JA, Bonami JR (1995) Taura syndrome in Penaeus vannamei: demonstration of a viral etiology. Dis Aquat Org 23:115-126

Editorial responsibility: Ken Hasson,

College Station, Texas, USA
La Fauce KA, Elliman J, Owens L (2007) Molecular characterization of hepatopancreatic parvovirus (pmergDNV) from Australian Penaeus merguiensis. Virology 362:397-403

Lightner DV (1996) A handbook of shrimp pathology and diagnostic procedures for diseases of cultured penaeid shrimp. World Aquaculture Society, Baton Rouge, LA

Lightner DV (1999) The penaeid shrimp viruses TSV, IHHNV, WSSV, and YHV: current status in the Americas, available diagnostic methods, and management strategies. J Appl Aquacult 9:27-52

> Lightner DV, Redman RM (1985) A parvo-like virus disease of penaeid shrimp. J Invertebr Pathol 45:47-53

> Lightner DV, Redman RM, Hasson KW, Pantoja CR (1995) Taura syndrome in Penaeus vannamei (Crustacea: Decapoda): gross signs, histopathology and ultrastructure. Dis Aquat Org 21:53-59

Maguire GB, Leedow MI (1983) A study of the optimum stocking density and feed rate for school prawns Metapenaeus macleayi (Haswell) in some Australia brackish water farming ponds. Aquaculture 30:285-297

Roubal FR, Paynter JL, Lester RJG (1989) Electron microscopic observation of hepatopancreatic parvo-like virus (HPV) in the penaeid prawn, Penaeus merguiensis de Man from Australia. J Fish Dis 12:199-201

Saitou N, Nei M (1987) The neighbor-joining method: a new method for reconstructing phylogenetic trees. Mol Biol Evol 4:406-425

Spann KM, Adlard RD, Hudson DA, Pyecroft SB, Jones TC, Voigt MOC (1997) Hepatopancreatic parvo-like virus (HPV) of Penaeus japonicus cultured in Australia. Dis Aquat Org 31:239-241

Sukhumsirichart W, Attasart P, Boonsaeng V, Panyim S (2006) Complete nucleotide sequence and genomic organization of hepantopancreatic parvovirus (HPV) of Penaeus monodon. Virology 346:266-277

Tamura K, Dudley J, Nei M, Kumar S (2007) MEGA4: Molecular Evolutionary Genetics Analysis (MEGA) software version 4.0. Mol Biol Evol 24:1596-1599

> Tang KFJ, Lightner DV (2005) Phylogenetic analysis of Taura syndrome virus isolates collected between 1993 and 2004 and virulence comparison between two isolates representing different genetic variants. Virus Res 112:69-76

> Tang KFJ, Poulos BT, Wang J, Redman RM, Shih HH, Lightner DV (2003) Geographic variations among infectious hypodermal and hematopoietic necrosis virus (IHHNV) isolates and characteristics of their infection. Dis Aquat Org 53:91-99

Zhang QY, Xiao F, Xie J, Li ZQ, Gui JF (2004) Complete genome sequence of lymphocystis disease virus isolated from China. J Virol 78:6982-6994

Submitted: February 6, 2008; Accepted: April 15, 2008

Proofs received from author(s): June 18, 2008 